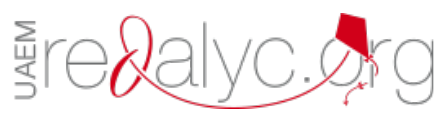

Centro Sur

ISSN: $2600-5743$

compasacademico@icloud.com

Grupo Compás

Ecuador

\title{
Didactic interaction through comics in the generation of resources
}

Espinosa Izquierdo, Jaime

Didactic interaction through comics in the generation of resources

Centro Sur, vol. 3, núm. 1, 2019

Grupo Compás, Ecuador

Disponible en: http://www.redalyc.org/articulo.oa?id=588861690010

Esta obra está bajo una Licencia Creative Commons Atribución-NoComercial-SinDerivar 4.0 Internacional. 


\title{
Didactic interaction through comics in the generation of resources
}

\author{
Interación didáctica mediante comics en la generación de \\ recursos \\ Jaime Espinosa Izquierdo jaime.espinosai@ug.edu.ec \\ Universidad de Guayaquil, Ecuador \\ http://orcid.org/0000-0002-3364-238X
}

Centro Sur, vol. 3, núm. 1, 2019

Grupo Compás, Ecuador

Recepción: 06 Noviembre 2018 Aprobación: 12 Febrero 2019

Redalyc: http://www.redalyc.org/ articulo.oa?id $=588861690010$

\section{BY-NC-ND}

Resumen: Al hablar de la Historia se habla de los hechos vividos por los próceres, personajes históricos que dieron su vida por liberar a los compatriotas. Se habla sin lugar a duda de todo lo que nos rodea sin que se nos escape algo, más nunca nos fijamos de cómo se nos ha impartido este conocimiento cuál fue, es y será la metodología de esa asignatura; considerando que la Historia pertenece a Estudios Sociales, y esta es una de las principales ciencias porque si no hubiese existido, de dónde cree usted que se hubiera podido plasmar tantas majestuosidades que se han dado a lo largo de la historia de nuestra existencia y poderlo saber ahora nosotros. A los estudiantes de educación básica se les debe de inculcar para fomentar los valores y enfrentarse a la sociedad, procurando igualdad de condiciones.

Palabras clave: Historia, aprendizaje, sistema educativo.

Abstract: When talking about history, we talk about the events experienced by the heroes, historical figures who gave their lives to free the compatriots. There is no doubt about everything that surrounds us without anything escaping us, but we never look at how this knowledge has been imparted to us what was, is and will be the methodology of that subject; considering that History belongs to Social Studies, and this is one of the main sciences because if it had not existed, where do you think it would have been possible to capture so many majestys that have occurred throughout the history of our existence and be able to know now we. Basic education students must be instilled to promote values and confront society, seeking equal conditions.

Keywords: History, learning, educational system, teaching.

\section{IINTRODUCTION}

Human beings are immersed in a digital age and still connected wired and we are, as Chomsky says, a bewildered flock; We live at a speed of vertigo and our capacity for peace of mind is diluted among the innumerable microchis of leisure that someone offers us in adequate doses in order to become inappropriate beings. Our society is a programmed society in which only a few have access to the keys to the program, while others cannot intervene except as mere spectators.

It is not intended to give an apocalyptic vision, but we do want to reflect and ask ourselves about some issues that directly affect the educational field.

Although it is true, both educational administrations and education professionals are increasingly committed to the use of other means, mainly those related to the treatment of information and that are presented in technical or technological support. 
On these aspects we will discuss in this article, trying to establish guidelines and criteria for the selection, use, elaboration and classification of teaching materials; analyzing the use of technological means; and seeing the didactic possibilities of these.

Didactic resources:

They are a set of elements that facilitate the completion of the teachinglearning process. These help students achieve mastery of a certain content. And therefore, access to information, the acquisition of skills, abilities and strategies, as well as the formation of attitudes and values.

Teaching resources, therefore, are those materials or tools that have utility in an educational process. Using an educational resource, an educator can teach a certain subject to his students.

This means that teaching resources help teachers to fulfill their educational function. In general, it can be said that these resources provide information, serve to put into practice what they have learned and, sometimes, they even constitute guides for students.

Suppose a teacher wants to teach students about global warming. To meet this objective, the teacher can use different teaching resources: he projects a film that shows the consequences of global warming, organizes a poster contest with the objective that students advise other young people on the subject and leads an expert to Give a talk to the class.

Teaching resources often appeal to creativity and student motivation. Following the previous example, students will have to draw their own conclusions from the film, demonstrate their imagination by creating the poster and reflect on the experience of the expert on this topic to take their example. The teaching-learning process, in this way, is more valuable with these resources than if only textbooks will be used.

Advantages of Teaching Resources:

The teaching materials constitute a complementary training resource that must be used in the appropriate manner and at the appropriate times.

The use of these materials has several advantages, such as:

Promotion of active education. Strengthening the effectiveness of learning.

Promotes teacher-student communication. Expansion of the student experience field. It allows the student to achieve learning by himself. Fan the interest. Guide learning. Easy correction

Promotion of cooperative activities. Promotion of distance education.

Achievement of student attention capture. They are useful for rationing the workload of both teachers and students. It decreases the time that must be dedicated for students to learn the subjects, because they work with their contents more directly. It helps to maximize motivation in students.

The use of didactic means favors both the student and the teacher since, with traditional materials such as blackboard or transparencies and new technologies, multimedia presentations, email, they favor the motivation and interest of students in the subject, Thanks to today's media several students who have successfully developed their studies 
online. For teachers it is a great advance since the corrections of work, thesis, practices, is faster and more comfortable.

Disadvantages of Teaching Resources:

Appearance of distraction. Addiction creation regarding the use of these media.

Deployment of minimum effort strategies. Reduction of group work and development of individualized behavior. Appearance of visual fatigue and saturation. Failure of new technologies, forcing the individual to reuse the traditional means mentioned above.

Lack of proper curricular planning.

Presence of passivity in the development of the activities carried out. High cost of acquisition and maintenance of computer equipment. Dizzying speed with which technical resources advance, making obsolete equipment in a very short period of time. Dependence on technical elements to interact and be able to use the materials. There is a risk of the student's separation from the rest of the participating agents (classmates and teachers) due to an impersonalization of the teaching.

The preparation of the materials necessarily implies an effort and a long period of conception. It is a totally different way of organizing teaching, which can generate rejection in some teachers who are adverse to change.

\section{MATERIALS AND METHODS}

This research is established as a documentary review of the tools available for the application of comics, the production of digital comics requires students to design, in cartoon format, that is, combining writing and image creation, a storyboard on a specific topic. Since comic strips are based on sequential frames, they help students determine the fundamental themes of any story and tell them graphically. Find here, both programs to produce them, and suggestions for use in the classroom.

With the unprecedented increase in digital resources offered online today, teachers have access to countless useful and quality computer tools, which they can use in their classes to enrich them and thus improve their students' learning.

Online application with Web 2.0 features to create comics. It offers a series of templates to select the number and layout of the boxes, various prefabricated characters, backgrounds and decorative items, etc. Students can create stories on topics related to the different subjects.

The first step is to select the type of comic (fast, classic, joke, large format, avatar, 4-Koma, length and freestyle). Next, select the most appropriate template for the story you want to tell. Then the characters to choose are chosen; This generates a new page with the comic in editable version (modify title, characters, balloons and texts).

Online application to create videos with some free and other paid options. With GoAnimate you can create comics in which the characters speak instead of using bullets and balloons with text.

The first thing is to click on the "Create your video" button, then choose the stage, the characters and write or record the dialogues. The 
tool offers the options of using ambient music for the video and creating your own characters. Android application that allows you to easily create comics from photographs. It offers several designs for the boxes and in each box you can insert a photograph and add one of the six types of globe, with their corresponding text. One of four available special effects can be applied to the images: old image, pencil drawing, cartoon and sepia.

\section{RESULTS}

Eydie Wilson plantea en su libro "Serious Comix" que la elaboración de Cómics engancha fácilmente a los estudiantes con actividades de escritura, de creación de ilustraciones y de narración secuencial de historias; las TIC facilitan la realización de estas actividades. Los docentes deben reflexionar acerca de cuáles de los procesos educativos que adelantan actualmente con sus estudiantes pueden impactarse positivamente con el uso educativo de Cómics (ver el punto 1 de este documento).

A manera de ejemplo, el uso educativo de Cómics resulta muy útil cuando los estudiantes deben:

Entender el lenguaje de las historietas y de las imágenes. Reconocer el tema de caricaturas o el tema expresado en, historietas, anuncios publicitarios y otros medios de expresión gráfica. Ordenar y completar la secuencia de viñetas que forman una historieta. Relacionar las imágenes con las palabras para explicar el significado de un mensaje.

Reconocer las formas de empezar y terminar algunas narraciones. Distinguir quién es el que produce un mensaje, quién es el que lo interpreta y qué papel juega cada uno. Elaborar instrucciones que sean lógicas y que tengan una secuencia. Expresar sentimientos y emociones mediante distintas formas gráficas y lenguajes.

Reconocer en los textos elementos como tiempo, espacio, acción y personajes. Entender las obras no verbales como producto de las comunidades. Humanas y descubrir qué estrategias usan para comunicar sus mensajes. Ordenar y completar la secuencia de viñetas que forman una historieta. Relacionar las imágenes con las palabras para explicar el significado de un mensaje.

Pensar antes de escribir un texto narrativo. Para ello: se define un tema; se busca y selecciona la información necesaria; se organiza la información en una secuencia lógica. Identificar elementos que forman parte de un texto; reconocer la función de los personajes, los ambientes, los diálogos y las escenas en una obra. Comprender que existen diversas formas de expresar las identidades (por ejemplo, la apariencia física, la expresión artística y verbal, y tantas otras).

Argumentar sobre dilemas de la vida cotidiana en los que distintos derechos o distintos valores entran en conflicto Argumentar sobre dilemas relacionados con exclusión. Crear un Cómic sobre un pasaje de una obra literaria leída en clase. Producir textos utilizando el lenguaje verbal y no verbal para expresar críticamente las ideas o para recrear realidades. 
Describir el impacto de algunos hechos políticos clave en las organizaciones sociales, políticas y económicas del país. Promover y defender los derechos humanos en su contexto escolar y comunitario. Representar procesos de trabajo para mejorar el uso y aprovechamiento de los recursos. Representar prácticas adecuadas para el uso y preservación de los recursos.

Uso educativo de los cómics y herramientas para elaborarlos.

La producción de Cómics digitales requiere que los estudiantes diseñen, en formato de historieta, esto es, combinando escritura y creación de imágenes, un guion gráfico sobre un tema específico. Como las tiras cómicas se basan en fotogramas secuenciales, estos ayudan a los estudiantes a determinar los temas fundamentales de cualquier historia y narrarlos gráficamente. Encuentre aquí, tanto programas para producirlos, como sugerencias para usarlos en el aula.

Uso educativo de los cómics y herramientas para elaborarlos

Con el aumento sin precedentes de recursos digitales ofrecidos hoy por Internet, los docentes tienen acceso a un sinnúmero de herramientas informáticas útiles y de calidad, que pueden utilizar en sus clases para enriquecerlas y mejorar así el aprendizaje de sus estudiantes.

Herramientas.

Pixton Aplicación en línea con características Web 2.0 para crear cómics. Ofrece una serie de plantillas para seleccionar el número y disposición de los recuadros, varios personajes prefabricados, fondos y artículos decorativos, etc. Los estudiantes pueden crear historias sobre temas relacionados con las diferentes asignaturas.

El primer paso consiste en seleccionar el tipo de cómic (rápido, clásico, chiste, gran formato, avatar, 4-Koma, largo y estilo libre). A continuación, se selecciona la plantilla más apropiada para la historia que se quiere contar. Luego se eligen los personajes a utilizar; esto genera una página nueva con el cómic en versión editable (modificar título, personajes, globos y textos).

GoAnimate Aplicación en línea para crear videos con algunas opciones gratuitas y otras de pago. Con GoAnimate se pueden crear cómics en los que los personajes hablan en lugar de utilizar viñetas y globos con texto.

Lo primero es hacer clic en el botón "Crea tu vídeo", luego elegir el escenario, los personajes y escribir o grabar los diálogos. La herramienta ofrece las opciones de utilizar música ambiental para el video y de crear personajes propios.

Comic Maker

Aplicación para Android que permite elaborar fácilmente Cómics a partir de fotografías. Ofrece varios diseños para los recuadros y en cada recuadro se puede insertar una fotografía y agregarle uno, de los seis tipos de globo, con su correspondiente texto. A las imágenes se les puede aplicar uno de cuatro efectos especiales disponibles: imagen antigua, dibujo a lápiz, dibujo animado y sepia.

Toondoo Con Toondoo los estudiantes pueden crear en línea sus propias historietas sobre cualquier tema. Para ello, utilizan los personajes, escenarios y objetos que ofrece la aplicación o crean los propios. Además, 
es posible cambiar la expresión del rostro y del cuerpo del personaje seleccionado, lo cual contribuye a que se adapte al texto de cada viñeta.

El primer paso consiste en registrarse en el sitio. Luego se debe seleccionar el diseño de las viñetas (entre 1 y cuadro recuadros) para la historieta a elaborar. Si el Cómic es largo, la herramienta permite unir varias historietas en un solo libro. A continuación, se arrastra a cada viñeta el fondo y los personajes prefabricados. Por último, se agregan los globos y sus respectivos textos.

Es posible crear una biblioteca con varios cómics y publicarlos en un Blog o página Web.

Bitstrips Aplicación en línea muy sencilla para crear cómics. Una vez seleccionado el número de viñetas, se procede a seleccionar y configurar cada uno de los fondos, personajes, objetos, efectos y figuras que irán en cada recuadro de la historieta. Posteriormente se agregan los globos con los textos. Por último, se aplican controles y filtros a personajes y globos.

Comic Strip It

Con Cómic Strip It los estudiantes pueden elaborar en sus dispositivos Android atractivas historietas. La aplicación permite utilizar las imágenes de la galería o tomar nuevas fotos directamente en el Cómic. Estas fotos se pueden agrandar o achicar, rotar y ubicar en diferentes posiciones. Al igual que en todos los programas para elaborar Cómics, se puede añadir título, globos con texto y aplicar efectos de imagen a cada fotograma. El Cómic resultante se puede compartir en todas las plataformas sociales.

Creaza Cartoonist

Programa para iPad que facilita crear historias. Permite guardar los trabajos en línea en una cuenta de Creaza para su posterior edición, distribución y exportación. Se pueden crear películas a partir de los dibujos animados creados en el iPad.

Características: Crear historias basadas en personajes prefabricados, accesorios y fondos realizados por diseñadores profesionales y artistas; cambiar el estado de ánimo y la expresión de los personajes; utilizar la cámara del iPad para añadir fotos a la historieta; guardar las historietas en línea y compartirlas con otros, o exportarlas a archivos PDF de alta resolución.

Por tanto, la incidencia de los recursos audiovisuales y de la objetividad de las cualidades que se interpretan al observar los comics, hacen despertar en los lectores el deseo de conocer desde otra óptica, para lo cual es necesario la participación de los actores que están inmersos en el mundo del aprendizaje, desde el docente, hasta el colaborador de la biblioteca donde reposan los libros. La difusión de la información contenida dentro de los comics tiene resistencia por cuanto no se los considera textos científicos, Es así que Gómez-Hernández, J. A. (2008) nos dice que "Es necesario incidir en la formación de los bibliotecarios y su conocimiento del mundo de los comics" Siendo los bibliotecarios quienes pueden recomendar el uso de este recurso. En tanto también considera que "Una biblioteca puede contribuir a la información sobre el comic, a la educación del gusto, a la comprensión de su lenguaje y a la reducción de los prejuicios existentes en torno a él." 


\section{DISCUSSION}

The objective of this work was to investigate what are the characteristics and conditions that the comic should have as mediation for learning. The work was developed by applying the synthetic analytical method, based on the analysis achieved by crossing information obtained from observations, in-depth interviews and documentary sources. The documentary sources included topics on image, teaching, teaching, learning, comics, humor, play and other related topics. As conclusions of this work, some are highlighted immediately, with the intention of summarizing the research, and presenting the conditions that researchers have found. The central conclusion reached by this work is the following: teachers can find, in the comic, an effective mediation for teaching, which must be supported by educational institutions. This investigation has contributed elements of judgment to conclude that the comic, as perhaps all means of mass communication, can be used as didactic mediation. However, to achieve this task, it is necessary to know the population to which the didactic mediation is directed; in addition, the thematic contents that have been chosen must be able to be developed with suitability, and these must be able to express themselves with professional quality in the format of the comic. At no time should you lose sight of the comic, like all media.

\section{Referencias}

Fernández, M. J., \& Ramiro, M. Á. (2014). Derechos humanos y comics: un matrimonio estéticamente bien avenido. Revista Derecho del Estado, 32(1), 243-280.

Gómez-Hernández, J. A. (2008). C. 2. El interés de las bibliotecas por el mundo de los comics.Anuario ThinkEPI, 3(1), 64-68

Hernández, J. A. G. (2007). Alfabetización informacional: cuestiones básicas. Anuario ThinkEPI, 1(1), 43-50.

Cacioppo J. \& Bertson G. (1992). Social Psychological Contributions to the Decade of the Brain Doctrine of Multilevel Analysis. The American Psychological Association, 47(8). 1019-1028.

Crespo, V., Puentes, I. \& Crespo, V. (2016). Neurociencias aplicadas a la comunicación política: Análisis de carteles electorales con Eye-Tracking Universidad de Vigo. En XESCOM, De los medios y la comunicación de las organizaciones a las redes de valor. Simposio llevada a cabo en el II Simposio de la Red Internacional de Investigación de la Comunicación Quito, Ecuador.

Dunagan J. (2012). Designer governance. Instituto para la Futuro, 44(9), 832 844.

García-Marza D. (2013). Neuropolítica y democracia: un diálogo necesario. Revista Internacional de Filosofia, 59(1), 171-182

Gutíerrez-Rubí A. (2009). La neuropolítica: conocer el cerebro para liderar las ideas. Revista de debat politic, 21(1), 84-87 